Advancing Nursing Practice in Cancer and Palliative Care 


\title{
Advancing Nursing \\ Practice in Cancer and \\ Palliative Care
}

\author{
Edited by \\ David Clarke, Jean Flanagan and \\ Kevin Kendrick
}


All rights reserved. No reproduction, copy or transmission of this publication may be made without written permission.

No paragraph of this publication may be reproduced, copied or transmitted save with written permission or in accordance with the provisions of the Copyright, Designs and Patents Act 1988, or under the terms of any licence permitting limited copying issued by the Copyright Licensing Agency, 90 Tottenham Court Road, London W1T 4LP.

Any person who does any unauthorised act in relation to this publication may be liable to criminal prosecution and civil claims for damages.

The authors have asserted their rights to be identified as the authors of this work in accordance with the Copyright, Designs and Patents Act 1988.

First published 2002 by

PALGRAVE MACMILLAN

Houndmills, Basingstoke, Hampshire RG21 6XS and

175 Fifth Avenue, New York, N.Y. 10010.

Companies and representatives throughout the world

PALGRAVE MACMILLAN is the global academic imprint of the Palgrave Macmillan division of St. Martin's Press, LLC and of Palgrave Macmillan Ltd. Macmillan ${ }^{\circledR}$ is a registered trademark in the United States, United Kingdom and other countries. Palgrave is a registered trademark in the European Union and other countries.

ISBN 978-0-333-77766-4 ISBN 978-1-349-88882-5 (eBook)

DOI 10.1007/978-1-349-88882-5

A catalogue record for this book is available from the British Library.

$\begin{array}{llllllllll}10 & 9 & 8 & 7 & 6 & 5 & 4 & 3 & 2 & 1\end{array}$

$\begin{array}{llllllllll}11 & 10 & 09 & 08 & 07 & 06 & 05 & 04 & 03 & 02\end{array}$ 


\section{Dedication}

As work on the book was being finished, our friend, colleague and co-editor Kevin Kendrick died suddenly and prematurely. Kevin was a devoted husband and father, a committed nurse and a dedicated writer and editor. He was also a passionate Liverpool FC supporter. Working on this book with Kevin represented many things. Editing this book was professionally satisfying, Kevin was instrumental in its initial development and contributed throughout the painstaking process of editing. As novices to the processes of book production it was rewarding to develop skills in this area in conjunction with a more seasoned editor. Like many other editors we would say that the process represented many months, indeed years of hard work and while this is true it somehow never felt like a chore. Most of all, the experience of editing this book with Kevin Kendrick was great fun. We are grateful for the time spent working together on this project.

David Clarke and Jean Flanagan 


\section{Contents}

List of Figures and Tables

Preface

Notes on the Contributors

\section{Part I}

1 The Advancing Role of Nurses in Cancer Care Jean Flanagan, David Clarke, Kevin Kendrick and Chrissie Lane

2 The Critical Essence of Advanced Practice Gosia Brykczynska

3 Beyond the Theory-Practice Gap: the Contribution of Theory in Nursing

David Clarke

4 Advancing Practice Through Research

Susan Holmes

\section{Part II}

5 Innovations in Cancer Therapeutics

Catherine M. Jack

6 Advancing Practice in Family Nursing Across the Cancer Continuum

Jean Flanagan, Susan Holmes and Doug McInnes

7 Spirituality: its Dynamics and Purpose in Nursing a Person With a New Diagnosis of Cancer

Kevin Kendrick and Nic Hughes

8 Advancing Practice in Cancer Care Ethics

Simon Robinson and Pauline Dodsworth 
9 Withdrawing Treatment: Ethical Issues at the End of Life Janet Holt

\section{Part III}

10 Making Advanced Practice a Reality:

An International Perspective

Jean Steel

11 Cancer and Palliative Care Nursing: the Influence of Policy Anita Fatchett

12 Developing Leadership for Advanced Practice Nursing Gill Collinson

13 Cancer Networks: Translating Policy Into Practice 


\section{List of Figures and Tables}

\section{Figures}

4.1 Implementation of evidence-based practice 68

4.2 Integrating research with clinical practice $\quad 72$

13.1 Cancer Nursing Leadership Pathway 246

\section{Tables}

$\begin{array}{lll}\text { 4.1 Benefits of evidence-based practice } & 70\end{array}$

$\begin{array}{lll}4.2 & \text { Practitioners' views of evidence-based practice } & 71\end{array}$

$\begin{array}{lll}4.3 & \text { The 'hierarchy' of evidence } & 71\end{array}$

4.4 Sources of evidence for nursing practice $\quad 74$

4.5 Top ten barriers to the utilisation of research in 82 oncology nursing practice

6.1 Family nursing assessment 


\section{Preface}

There is no doubt that the scope and nature of cancer and palliative care nursing is expanding and extending. The central aim of this book is to unravel the intricacies of extended and expanded practice in this field. As cancer and palliative care nursing is complex and related to the diverse needs and concerns of patients this analysis is broadly based. Thus, the contributions range from the technological aspects of care, to its moral, spiritual and ethical dimensions. Other contributions focus on family care and potential for expansion of the nurse's role in this important area. Chapters draw upon several different knowledge sources, both from within the domain of nursing science, where the application to cancer and palliative care is overt, to a broad range of other sources, philosophical, psychological and sociological. Advances in cancer and palliative care nursing are thus analysed from an informed and critical perspective.

The central theme of Advancing Nursing Practice in Cancer and Palliative Care relates to the highly contentious and deeply confused professional debate on the nature of 'advanced nursing practice' or 'higher level practice' within a specific context. Readers will quickly notice that the terms 'advanced', 'advancing', 'higher level', and 'expert' are used often and sometimes they are used interchangeably. Likewise the terms 'nurse-led' services and 'cancer nursing practitioner' and 'nurse consultant' are used as they describe particular advances in cancer nursing practices. We make no apologies for using this variety of terms throughout the book; we would welcome clarity of definition in these areas but do not see this as the purpose of this book. While we have sympathy with the view that the language used to describe nursing work is confusing, these terms are used in the everyday language of practising nurses and are also expressed as part of nursing policy. Moreover, these terms reflect the many ways in which professional boundaries are currently being re-negotiated in changing service provision.

While the book sets out a vision for advancing cancer and palliative care nursing practice, it also offers some direction on how to achieve that vision. Thus the final parts of the book are devoted to consideration of issues of leadership, management and policy. These elements are not only necessary but essential in order to make 'advanced' or 'advancing nursing practice' a reality. 
We hope that you find this book useful, stimulating and challenging. We are deeply grateful to the many contributors who rose to the challenge in helping to articulate the ways in which 'advanced cancer and palliative care nursing' can contribute to patient care. 


\section{Notes on the Contributors}

Gosia Brykczynska is International Nursing Consultant, International Department of the Royal College of Nursing.

David Clarke is Lecturer in Nursing, at the University of Leeds.

Gill Collinson is an independent consultant, and Programme Associate, at the Centre for Policy and Practice Development, University of Leeds.

Pauline Dodsworth is Senior Nursing Lecturer, University of Leeds and St Gemma's Hospice, Marie Curie Nurse.

Jean Flanagan is Education Development Manager, Macmillan Cancer Relief. Anita Fatchett is Senior Lecturer (Nursing), at Leeds Metropolitan University, and a non-executive director, Wakefield West Primary Care Trust.

Janet Holt is a Lecturer at the University of Leeds.

Nic Hughes is Macmillan Lecturer, Macmillan Education Unit, at the University of Leeds.

Catherine Jack is Macmillan Lecturer, Macmillan Education Unit, at the University of Leeds.

Claire Kelly is Network Lead Nurse, with the Cancer Care Alliance, South Tees, South Durham and North Yorkshire.

Kevin Kendrick was formerly, Lecturer in Nursing, at the University of Leeds.

Chrissie Lane is a Network Lead Nurse.

Simon Robinson is Senior Anglican Chaplain and Lecturer in Theology, at the University of Leeds.

Susan Holmes is Director of Research and Development and Professor of Nursing, Faculty of Health, at Canterbury Christ Church University College.

Jean Steel is Professor and Chair, Advanced Practice Nursing, and Director, Centre for International Healthcare Education, Massachusetts General Hospital, Institute for Healthcare Professionals, Boston, Massachusetts.

Doug McInnes is senior lecturer in Research, Centre for Nursing Research and Practice Development, Faculty of Health, at Canterbury Christ Church College. 